URBANEK, R. P., AND T. A. Bookhout. 1992. Nesting of Greater Sandhill Cranes on Seney National Wildlife Refuge, p. 161-167. In D. A. Wood [ed.], Proc. 1988 N. Am. Crane Workshop.

Voss, K. S. 1977. Agonistic behavior of the Greater Sandhill Crane, p. 63-85. In R. D. Feldt, [ed.], Proc. Symp. on the eastern population of the Greater Sandhill Crane. Michigan City, Indiana.
Walkinshaw, L. H. 1949. The Sandhill Crane. Cranbrook Inst. of Science, Bull. 29, Bloomfield Hills, MI.

WARBURG, G. 1952. Distraction behaviour of Redshank. Br. Birds 45:37-38.

Yosef, R., AND D. YoseF. 1992. Hunting behavior of Audubon's Crested Caracaras. J. Raptor Res. 26:100-101.

\title{
VOICE, PLUMAGE AND NATURAL HISTORY OF ANTHONY'S NIGHTJAR (CAPRIMULGUS ANTHONYI)'
}

\author{
MARK B. RobBins ${ }^{2}$ AND Robert S. RIDGELY \\ Department of Ornithology, Academy of Natural Sciences, 1900 Benjamin Franklin Parkway, \\ Philadelphia, PA 19103 \\ Steven W. CardifF \\ Museum of Natural Science, Louisiana State University, Baton Rouge, LA 70803
}

Key words: Caprimulgus anthonyi; natural history; vocalizations.

Caprimulgus anthonyi remains one of the least known Neotropical nightjars. When Schwartz (1968) suggested elevating $C$. anthonyi back to species status, nothing was known beyond the minimal label data of the two specimens that he examined (unbeknownst to him, a third specimen existed in Paris [Berlioz 1937]). Here we summarize information on this species gathered since Schwartz's review.

Caprimulgus anthonyi was originally described as a species (Chapman 1923), but was subsequently treated, without explanation for the change, as a subspecies of the widespread species Caprimulgus parvulus by Peters (1940) and Meyer de Schauensee (1966). Schwartz (1968) re-emphasized the significant plumage differences between $C$. anthonyi and all populations of $C$. parvulus and suggested that $C$. anthonyi was better regarded as a separate species. Schwartz also noted similarities between $C$. anthonyi and $C$. cayennensis in certain plumage features, most notably in tail pattern, and in apparent habitat preferences. However, he refrained from making any definitive statements about the relationships of these taxa, because at that time the vocalizations of $C$. anthonyi were unknown. The song of $C$. anthonyi has now been documented (Fig. 1), and it bears no resemblance to either $C$. parvulus or $C$. cayennensis. Unlike the latter two species, both of which have complicated, multiple-noted songs (Hardy et al.

\footnotetext{
I Received 30 June 1993. Accepted 26 October 1993.

2 Present address: Division of Ornithology, Museum of Natural History, University of Kansas, Lawrence, KS 66045 .
}

1989), C. anthonyi's song is a simple, two-noted "treeow," about $0.24 \mathrm{sec}$ in duration. We know of no other Neotropical caprimulgid whose song is similar to anthonyi's, and thus the vocalizations of $C$. anthonyi do not offer any clues as to its relationships.

\section{DISTRIBUTION}

Twenty-four specimens ( 21 skins, two skeletons, one alcoholic; ANSP, LSUMZ, MECN) of $C$. anthonyi have been collected since Schwartz's treatment. Prior to field work in northern Peru by the Louisiana State University Museum of Natural Science (LSUMNS) staff in the 1970s and early 1980s, this nightjar had been recorded from only three localities in the drier Pacific Ecuadorian lowlands and adjacent arid foothills. These sites were widely scattered and demonstrated that $C$. anthonyi was at least locally distributed from along the coast near the Colombian border (Vaquería, Prov. Esmeraldas) to within $60 \mathrm{~km}$ of the Peruvian border (Portovelo, Prov. El Oro). The LSUMNS surveys in Peru extended $C$. anthonyi's range southward in the arid Pacific lowlands as far as Las Pampas, Depto. Lambayeque. An isolated population was also discovered at the northern end of the upper Rio Marañon Valley (Bagua, Depto. Amazonas; near Jaén, Depto. Cajamarca; Fig. 2). A number of other avian taxa share a similar distribution pattern (e.g., Otus roboratus, Veniliornis callonotus, Myiarchus phaeocephalus, Mimus longicaudatus). Additional work by ANSP workers in Ecuador has further delineated this species' range there (Fig. 2). Caprimulgus anthonyi has been recorded as high as $750 \mathrm{~m}$ in the arid foothills of southern Ecuador (Portovelo, Prov. El Oro, American Museum of Natural History, New York, 166785; near Mangaurcu, Prov. Loja, ANSP 185144-5) and at $775 \mathrm{~m}$ in the Marañon Valley (near Jaén, Depto. Cajamarca, LSUMZ 87307). From Figure 2, it appears that $C$. anthonyi's range 
4

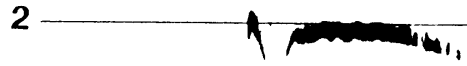

$\mathbf{0}$

0.5

TIME (SEC)

FIGURE 1. Spectrogram of song of Caprimulgus anthonyi. This example was recorded at dawn on 12 January 1985, near the Río Tocto, Depto. Lambayeque, Peru, by Thomas Schulenberg.

is fairly extensive. However, the arid habitat in which it is found in northwestern Ecuador is restricted to a narrow ribbon found locally along the coast from near Bahía de Caráquez, Prov. Manabí, to the above Vaquería site (Chapman 1926). In northwestern Peru, much of the arid littoral zone is devoid of vegetation, and presumably $C$. anthonyi is not found there, except possibly during exceptional years of abundant precipitation. We suspect that during non-El Niño years, $C$. anthonyi is restricted in Pacific Peru to the gently rolling hills near the base of the west slope of the Andes. Presumably, the Marañon population is more widely distributed than the two known localities indicate.

\section{PLUMAGE MORPHOLOGY}

Of the two specimens that Schwartz (1968) examined, one was marked as a male and the other a female. The male had a white wing band, whereas the female was described as having a "buffy rufous" band. With the accumulation of additional material (morphometrics in Table 1), it is now clear that the female that Schwartz examined was a juvenile, as adults of both sexes have a white wing band, which is restricted to the outer five primaries (6th through 10th). The wing-band's extent is slightly greater in males than in females. The sexes do not significantly differ in wing and tail length, nor mass $(P<0.05$; Table 1$)$. Tail pattern, however, does differ. In adult males, the inner webs of the outer two pairs of rectrices are entirely white (see photo in Schwartz [1968]). Some individuals have some blackish along the shaft of the apical half. Adult females have white on only the outer pair of rectrices.

Based on the twenty specimens at hand, we can state the following on molt and plumage sequences in this species. A short-tailed, juvenile female (LSUMZ 100639) taken with an adult male (LSUMZ 100640; testes $6 \times 3 \mathrm{~mm}$ ) on 29 May 1981 near Las Pampas, Peru, is characterized by having a pale buff throat, outer rectrices with a largely uniform, pale buff inner web, and primaries extensively barred with rufous distally. The primaries are not grown in enough to determine the color of the wing-band. Another juvenile female (ANSP 185144; bursa $7 \times 4.5 \mathrm{~mm}$ ) taken on 17 August 1992, east of Mangaurcu, Prov. Loja, Ecuador, also has a buffy-white throat and a uniform, pale buff inner web to the outer rectrix. Unlike the above juvenile female, the primaries are fully grown in: the wing band is a uniform buff color. The tips of all wing feathers are narrowly edged with buff-white. Individuals in presumed first basic plumage differ from the juvenal plumage by possessing a white throat, barred (LSUMZ 87306) or white (LSUMZ 87307) outer rectrices, and due to the arrested primary molt, one or more retained juvenal outer primaries with a buffy band. Primary molt appears to proceed from the innermost outward, which is consistent with the sequence for at least the Chuckwill's-widow (Caprimulgus carolinensis; Rohwer 1971) and several Old World Caprimulgus (Cramp 1985). For example, an immature female specimen (ANSP 181512) taken on 25 August 1989 near Santa Rosa, Prov. El Oro, Ecuador, has worn outer three primaries with a buffy band, whereas the other primaries are fresh (6th and 7th with a white band; 7th still sheathed). Another immature (ANSP 185148; male, bursa $5 \times 4$ $\mathrm{mm}$ ) collected on 24 June 1992, near Puerto López,

TABLE 1. Mean ( \pm SD) of selected measurements of Caprimulgus anthonyi.

\begin{tabular}{rccc}
\hline \hline$n$, sex & $\begin{array}{c}\text { Mass' } \\
\text { (grams) }\end{array}$ & $\begin{array}{c}\text { Wing (chord) } \\
(\mathrm{mm})\end{array}$ & $\begin{array}{c}\text { Tail } \\
(\mathrm{mm})\end{array}$ \\
\hline 10 ô̊ิ & $35.2( \pm 2.9)$ & $131.7( \pm 3.9)$ & $94.9( \pm 2.3)$ \\
9 ㅇํ & $36.6( \pm 3.8)$ & $134.1( \pm 2.7)$ & $93.2( \pm 4.3)$ \\
\hline
\end{tabular}

' Excludes suspect mass for three Marañón specimens. 


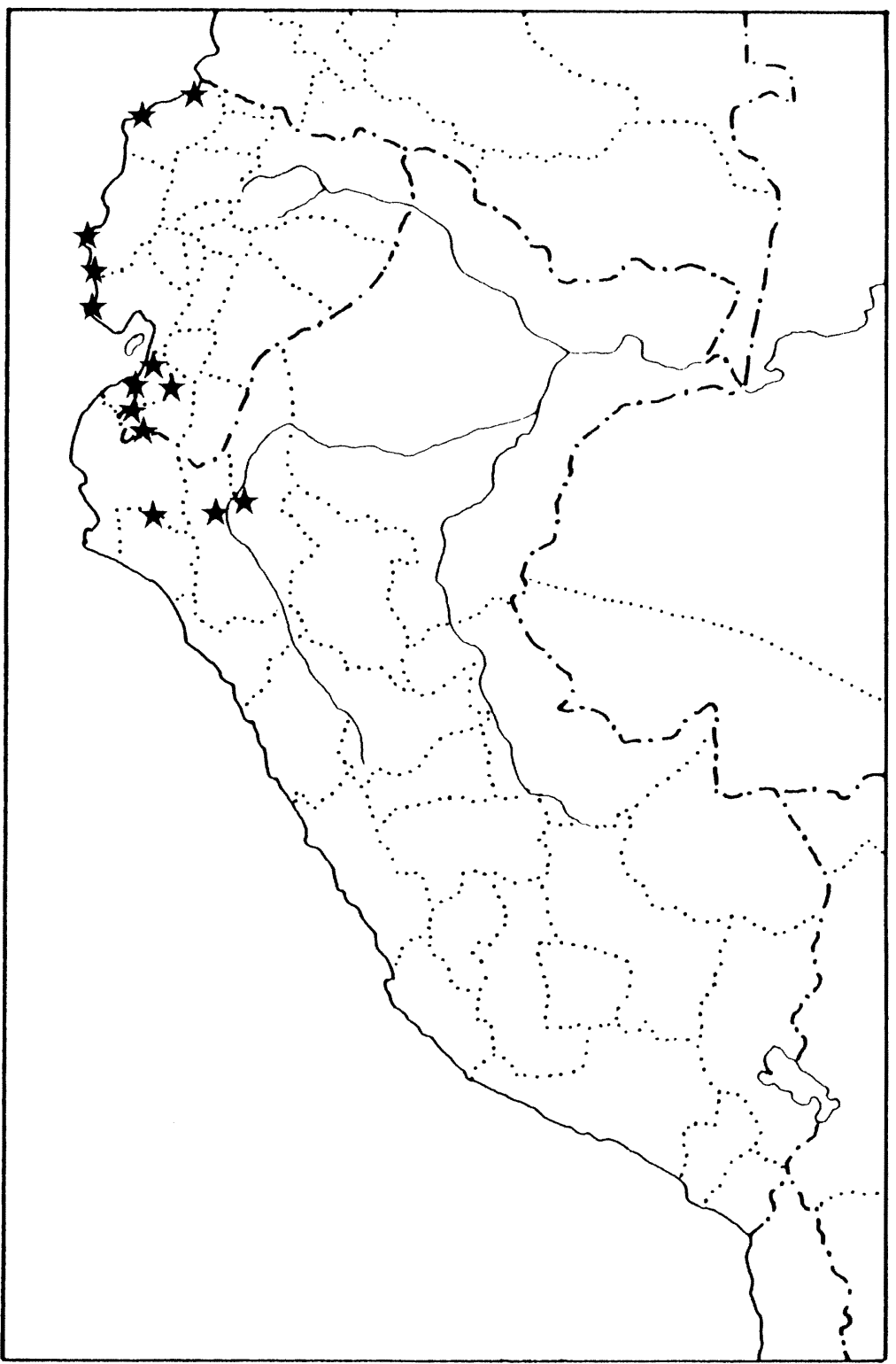

FIGURE 2. Stars denote localities where Caprimulgus anthonyi has been recorded. A few of the stars in Ecuador represent more than one locality.

Prov. Manabí, Ecuador, has the outer four primaries with a buffy band, with the 6 th being replaced; band color is not visible on the latter primary.

The tail pattern of young birds also differs from that of adults. Birds with buffy wing bands (both juveniles and presumed first-year birds) have a dusky, unicolored outer web to the outer two pair of rectrices similar to that of adults. However, their inner web is either mottled with irregular bands of dark brown on a dusky background or is a dull, pale buff color. The central pair of rectrices is molted first, followed by the outermost pair. The above mentioned immature female
(ANSP 181512) and an immature male (ANSP 185148) have fresh central rectrices, the outer two are just coming in, whereas the others are heavily worn. An adult male (ANSP 181511) taken on the same date and locality as ANSP 181512 exhibits a similar molt pattern.

Although very little has been published on rectrix molt in New World Caprimulgus, tail molt in C. anthonyi appears to be similar to that reported for $C$. carolinensis. From only eight specimens that exhibited rectrix molt, Rohwer (1971) concluded that C. carolinensis initially replaced the central rectrices, with the second from the outer most pair (R4) replaced last; 
otherwise, he was unable to discern a pattern. Mengel (1976) collected an adult female $C$. carolinensis that had simultaneous rectrix replacement. Rectrix replacement of Old World Caprimulgus generally proceeds from inner to outer pairs (Cramp 1985).

\section{NATURAL HISTORY}

Caprimulgus anthonyi is restricted to arid grassy scrub and adjacent pastures and woodland borders. Limited observations indicate that $C$. anthonyi may be somewhat nomadic or at least move seasonally and breed in response to rainfall, like many other bird species found in this region (Marchant 1958, 1959; Cardiff, pers. obs.). For example, in 1981 at the Las Pampas, Peru locality, C. anthonyi arrived following droughtbreaking rains in February and early March. A severe drought lasted at this locality for at least four years. During April and May, Cardiff occasionally heard individuals singing in the evening or flushed them during daylight hours along brushy washes through desert scrub, and in mature, brushy mesquite woodlots. All individuals flushed in daylight had been on the ground. On 7 April at dusk, one was heard singing and observed hawking for insects low over the bush tops along a brushy wash. On $12 \mathrm{May}$, an adult male (LSUMZ 100638 ; testes $10 \times 6 \mathrm{~mm}$ ) was collected along a brushy wash after being flushed during daylight. The same day, an adult female (LSUMZ 100637; ovary mass $5 \times 3$ $\mathrm{mm}$ ) was found dead on a paved highway through a mosaic of fallow farmland and mesquite woodlots. In September 1983, following heavy El Niño rains earlier in the year, Cardiff again occasionally heard $C$. anthonyi at Las Pampas in second-growth mesquite thickets in farmland.

On 3 April 1989, near Huaquillas, Prov. El Oro, southwestern Ecuador, Ridgely found a single bird vocalizing at the edge of deciduous woodland. Heavy rains had drenched the Huaquillas area during the previous several months. The forest was lush with heavy ephemeral viny growth (similar in appearance to vegetation at this site following the 1982-1983 El Niño event), and there was even considerable standing water in low areas with poor drainage.

Heavy rains associated with another El Niño event arrived in mid-March 1992 along much of the Ecuadorian coast. On 5 March, about a week before the advent of the rain, N. Krabbe collected one (MECN 6012) of three vocalizing birds between Puerto López and Machalilla National Park, Prov. Manabí. This specimen had moderately enlarged testes, $6 \mathrm{~mm}$ in length. At dusk on 7 and 8 April 1992, about 4-5 km north of Zapotillo, Prov. Loja, Robbins, G. Rosenberg, F. Sornoza and M. Jácome located seven birds by using prerecorded tapes of this nightjar's song. No birds were heard calling without using playback; unfortunately, we were unable to collect any to determine their breeding condition. On the evening of the 8th, a male was observed chasing another bird (sex ?) in broad loops at least $10 \mathrm{~m}$ above the desert floor. Rains at this locality had transformed a normally barren, badly overgrazed area into a relatively lush habitat. All other bird species encountered in this area were in some stage of breeding (ANSP, MECN specimens).

From 20 to 24 June 1992, four male $C$. anthonyi (three adults, one immature) were collected at three sites along the Ecuadorian coast in Prov. Guayas and Manabí by Ridgely, Sornoza, T. Davis, and Jácome. All three of the adult birds had enlarged testes, ranging from $7 \times 4$ to $9 \times 6.5 \mathrm{~mm}$. Three females (two adults, one immature) were taken along a road bordered by arid deciduous forest by Davis and Sornoza between 15 and 18 August 1992, east of Mangaurcu, Prov. Loja, in extreme southwestern Ecuador. Both adults had enlarged ovaries, with one having a follicle of $3 \times 3 \mathrm{~mm}$.

Although 1992 was a very wet year in western Ecuador, rainfall was even greater there during 1993; rains began in January and continued into May. On 21 January, one presumed male was observed singing (after being stimulated by a pre-recorded tape) in a recently created pasture in coastal scrub near Puerto Cayo, Prov. Manabí. A week later on 28 January, near Atacames, Prov. Esmeraldas, close to the northern terminus of anthonyis distribution, this nightjar was common, with at least $10-15$ presumed males heard singing in extensive pastures and small patches of degraded secondary growth by Ridgely and F. Sornoza. One male that was collected had greatly enlarged testes, $10 \times 5 \mathrm{~mm}$ (ANSP 186121 ). We suspect that anthonyi may in fact be increasing in this region of Ecuador as a result of ongoing deforestation. At least three non-vocalizing birds were found in pastures on 15 April 1993, Manglares-Churute Ecological Reserve, Prov. Guayas by Ridgely et al. This nightjar was common southwest of Zapotillo, Prov. Loja, from 20 to 22 April 1993, with a few birds heard singing.

Ridgely and Robbins observed about ten non-vocalizing individuals (ANSP 181510-12; all with small gonads) feeding in damp grassy meadows away from any wooded habitat on 25 August 1989, near Santa Rosa, Ecuador. At least one non-vocalizing individual was found again at this locality on 11 August 1990 (S. Hilty et al., pers. comm.). Interestingly, at the same time that these non-vocalizing birds were found near Santa Rosa at sea level, a singing individual was seen at $750 \mathrm{~m}$, near Portovelo, Prov. El Oro on 4 August 1990 (J. Arvin et al., pers. comm.). No rainfall data are available for the latter locality and date.

From these data it seems that the onset of breeding in $C$. anthonyi is timed to the arrival of rains, which are highly irregular but usually commence between December and March. During years of above average rainfall, e.g., during an El Niño event, breeding in $C$. anthonyi may be prolonged, with perhaps more than one clutch produced. On the other hand, perhaps in years when there is little to no rain this nightjar may forego breeding altogether. The following dates summarize when juveniles have been collected (one specimen/date, except 16 November, when two were collected): 12 May 1981, 24 June and 17 August 1992, 25 August 1989, 3 September 1901, and 16 November 1978.

Where stomach contents were noted, all individuals $(n=15)$ contained insects. Stomach contents of three specimens collected from a wet pasture at the above Santa Rosa locality contained a total of eleven beetles (family Scarabeidae, subfamily Dynastini, tribe Cyclocephalini) and one unidentified moth. Specimens collected near Las Pampas, Depto. Lambayeque, Peru, in May 1981 also contained the remains of unidentified beetles and moths. Finally, an immature female taken 
at the Mangaurcu, Ecuador, locality had grasshopper remains in its stomach.

We thank Miguel Moreno, Director of the Museo Ecuatoriano de Ciencias Naturales (MECN), Quito, and the Ministerio de Agricultura, Quito, especially Sergio Figueroa, for support and authorization of our ongoing research program in Ecuador. ANSP field work during 1990-1992 was supported by the MacArthur Foundation. Thomas Schulenberg kindly provided the spectrogram and he and Van Remsen made helpful comments on the manuscript. John Arvin, Steve Hilty, and Niels Krabbe generously shared their unpublished observations with us, and José Santisteban identified stomach contents.

\section{LITERATURE CITED}

Berlioz, M. J. 1937. Note sur quelques oiseaux rares ou peu connus de l'Equateur. Bull. du Muséum National d'Histoire Naturelle, 2nd serie, tome IX, no. 2.

Chapman, F. M. 1923. New South American birds. Amer. Mus. Nov. no. 67.

Chapman, F. M. 1926. The distribution of bird-life in Ecuador. Bull. Am. Mus. Nat. Hist. 55:1-784.

Cramp, S. [ED.]. 1985. Handbook of the birds of Eu- rope the Middle East and North Africa. The birds of the Western Palearctic. Vol. IV. Oxford Univ. Press, Oxford, England.

Hardy, J. W., G. B. Reynard, and B. B. Coffey. 1989. Voices of the New World nightjars and their allies. ARA Records, Gainesville, FL.

Marchant, S. 1958. The birds of the Santa Elena Peninsula, S.W. Ecuador. Ibis 100:349-387.

MARChANT, S. 1959. The breeding season in S.W. Ecuador. Ibis 101:138-152.

Mengel, R. M. 1976. Rapid tail molt and temporarily impaired flight in the Chuck-will's-widow. Wilson Bull. 88:351-353.

MeYer DE SChauenSEe, R. 1966. The species of birds of South America and their distribution. Livingston Publishing, Narbeth, PA.

Peters, J. L. 1940. Check-list of the birds of the world, Vol. 4. Harvard Univ. Press, Cambridge, MA.

RoHwer, S. A. 1971. Molt and the annual cycle of the Chuck-will's-widow, Caprimulgus carolinensis. Auk 88:485-519.

Schwartz, P. 1968. Notes on two Neotropical nightjars, Caprimulgus anthonyi and C. parvulus. Condor 70:223-227.

\title{
EFFECTS OF HABITAT STRUCTURE ON PATCH USE BY LOGGERHEAD SHRIKES WINTERING IN A NATURAL GRASSLAND'
}

\author{
Felipe Chavez-Ramirez and Dale E. Gawlik \\ Department of Wildlife and Fisheries Sciences, Texas A\&M University, \\ College Station, $T X 77843-2258$ \\ Felipe G. Prieto \\ United States Fish and Wildlife Service, Matagorda Island \\ National Wildlife Refuge, P.O. Box 100, Austwell, TX 77950 \\ R. Douglas Slack \\ Department of Wildlife and Fisheries Sciences, Texas A\&M University, \\ College Station, $T X$ 77843-2258
}

Key words: Conservation; habitat use; Lanius ludovicianus; Loggerhead Shrike; management; perch.

Recent attempts to explain the decline of many Loggerhead Shrike (Lanius ludovicianus) populations (Bystrak and Robbins 1977, Geissler and Noon 1981, Morrison 1981) have focused on habitat loss due to modern agricultural practices (Brooks and Temple 1990; Smith and Kruse 1992; Yosef and Grubb 1992, 1993; Gawlik and Bildstein 1993). Degree of habitat loss is consistent

\footnotetext{
${ }^{1}$ Received 21 September 1993. Accepted 23 September 1993.
}

with the differential declines of shrike populations observed in various regions of the United States. Populations in the intensive agricultural areas of the midwest, south, and southeast are declining more severely than those in the western United States dominated by grasslands (Arbib 1977, Morrison 1981). Although a considerable amount of information exists on shrikes in agricultural systems, none is available regarding habitat changes and the mechanisms affecting shrikes in natural grasslands. Understanding shrike use of natural grasslands can lead to a better understanding of shrike response to land-use changes.

Recent emphasis on conservation of wintering grounds and migration corridors (Terborgh 1992) have underscored the significance of identifying essential 